\title{
Silver (I) Ion Removal Efficiency of Activated Carbon Prepared from Terminalia-bellerica (Barro) Seed Stone
}

\author{
Mandira Pradhananga Adhikari', Sandeep Sharma Lamsal ${ }^{* 1}$ \\ ${ }^{1}$ Central Department of Chemistry, Tribhuvan University, Kirtipur, Kathmandu, Nepal \\ *CorrespondingE-mail: sharmasan525@gmail.com
}

(Received: September 9, 2020; Revised: January 8, 2021; \& Accepted: January 12, 2021)

\begin{abstract}
Phosphoric acid-activated Terminalia-bellerica (Barro) seed stone powder was carbonized in a muffle furnace at three different temperatures $\left(300,400\right.$, and $\left.500^{\circ} \mathrm{C}\right)$. The activated carbons (BAC-300, BAC-400, and BAC-500) were characterized by using Fourier transform infrared (FTIR) spectroscopy, scanning electron microscopy (SEM), methylene blue number, and iodine number. The iodine number $(357 \mathrm{mg} / \mathrm{g})$ and specific surface area $\left(537 \mathrm{~m}^{2} / \mathrm{g}\right)$ were a maximum for BAC-400. The BACs followed Langmuir adsorption isotherm and the maximum methylene blue adsorption capacity was $212.77 \mathrm{mg} / \mathrm{g}$. The silver ion removal efficiency was a maximum at $\mathrm{pH} 6,3 \mathrm{mg} / \mathrm{L}$ of adsorbent dose, and $20 \mathrm{mg} / \mathrm{L}$ of silver ion concentration. The BAC-400 could adsorb $40 \%$ of silver ion within 5 mins with the initial $\mathrm{Ag}(\mathrm{I})$ ion concentration of $20 \mathrm{mg} / \mathrm{L}$ and an adsorbent dose of $1 \mathrm{mg} / \mathrm{L}$. The percentage of adsorption enhanced to $100 \%$ with the increment of adsorbent dose to $3 \mathrm{~g} / \mathrm{L}$. The adsorption kinetics of silver (I) ion on BAC-400 was well fitted to pseudo-second-order kinetics suggesting the chemisorption of silver ions. All the results attributed that low-cost viable adsorbent can be prepared from Barro seed stone for the efficient removal of silver ion from aqueous solution.
\end{abstract}

Keywords: Activated carbon, Barro seed stone, muffle furnace, silver adsorption.

\section{Introduction}

Silver nanoparticles are incorporated in different fields such as photovoltaic cells, biological and chemical sensors, etc. [1-4]. Recently there are hundreds of products such as disinfectants, cosmetics, food packaging materials, cleaning agents, etc. which utilize silver nanoparticles [5]. Besides, silver nanoparticles induce structural and morphological changes into bacterial cells, which lead to cell death [6,7]. Despite several advantages of silver nanoparticles, they have potential impacts on human health and ecosystems [8, 9]. The most common health effects associated with continuous exposure to silver are skin discoloration, eye irritation, liver and kidney damage, etc. $[9,10]$. It was reported that the widespread commercial and biomedical applications of silver nanoparticles enhanced the significant amounts of the silver ions into wastewater $[11,12]$ hence to natural water systems. World Health Organization (WHO) and the US Environmental Protection Agency (EPA) classified soluble silver ions as hazardous substances in water systems and limited the level of silver in drinking water to be $100 \mu \mathrm{g} / \mathrm{L}$ [13]. Therefore, it is necessary to remove silver ions from water to eliminate the toxicity of the water.
Adsorption is one of the simplest, effective, and widely used techniques for water treatment processes. The adsorption efficiency of an adsorbent depends upon various factors such as the nature of the adsorbent, $\mathrm{pH}$ of the medium, etc. [14]. Activated carbon is one of the versatile adsorbents because it has a large surface area, a high microporosity, and a high degree of surface reactivity, hence, high adsorption capacity [15]. Currently, various studies have been conducted to develop activated carbon using different precursors such as banana peels [16], bamboo cane [17], corn cob [18], rice husk $[19,20]$, apple waste [21], coconut shell [22], etc., for the treatment of water. However, there is still a lack of low-cost and efficient activated carbon for the removal of hazardous metals such as silver ions. Therefore, the use of cheap lignocellulosic materials with a high carbon content will be an alternative to develop low-cost and efficient adsorbent. However, the adsorption capacity of adsorbent is highly influenced by functional groups present on the surface of the activated carbon. The carbon matrix containing carboxyl, carbonyl, phenols, lactones, quinones, etc. functional groups are efficient for adsorption because they have better ion exchange and 
adsorptive characteristics [23]. Terminalia-bellerica is a large deciduous tree found throughout South Asia including Nepal. The Spectroscopic analysis suggested that the fruit nut of Terminalia bellerica contains hydroxyl and carboxyl acid groups and 3, 4,5-trihydroxy benzoic acid (gallic acid) has been isolated from it [24]. Hence, the seed stones which are waste materials obtained from Terminalia-bellerica (Barro) was used as a precursor for the preparation of activated carbon to remove silver ions from an aqueous solution.

\section{Materials and Methods}

The Barro (Terminalia-bellerica) fruits were collected from the Ghiring rural municipality of Tanahun district, Nepal. The outer fleshy part of fruits was removed and the hard woody part was washed with tap and distilled water several times and sun-dried for one week, then dried at $110^{\circ} \mathrm{C}$ in an air oven for 24 hours. The dried seed stone was ground with an electric grinder and mixed with the required amount of phosphoric acid $(50 \%)$ in the ratio of $1: 1$ by weight of phosphorus to Barro seed stone powder with continuous stirring for 24 hours. The phosphoric acid impregnated, dried Barro seed stone was kept in a porcelain basin and carbonized at 300 (BAC-300), 400 (BAC-400), and 500 BAC-500) in a muffle furnace for 3 hours. After cooling, the carbonized carbon was sieved through the mesh of $212 \mu \mathrm{m}$ size and washed with $1 \% \mathrm{NaHCO}_{3}$ solution to neutralize phosphoric acid. The activated carbon was then washed with distilled water until the $\mathrm{pH}$ of the solution becomes 7 and dried in an oven at $110^{\circ} \mathrm{C}$ for 24 hours.

The proximate analysis of Barro seed stone was determined by the ASTM D2867-95 method. The thermal behavior of Barro seed stone was observed by using a TG analyzer (Pyris 1, Perkin Elmer, USA) at Chonbuk National University, South Korea. The sample was heated from 30 to $800^{\circ} \mathrm{C}$ at a rate of $5^{\circ} \mathrm{C}$ $\mathrm{min}^{-1}$ in $\mathrm{N}_{2}$ environment. The surface morphology of the activated carbon was studied by using scanning electron microscopy (FE-SEM, Hitachi S-7400, Japan). The surface functional groups of activated carbon were determined by recording the FTIR spectra on Thermo Electron Corporation, Nicolet 4700 at room temperature. The percentage of transmission of the samples was recorded between 400 and $4000 \mathrm{~cm}^{-1}$. The iodine number was determined by the ASTM D460794 method. In this method, $0.1 \mathrm{~g}$ Barro seed stone activated carbon (BAC) was added to $5 \mathrm{~mL}$ of $5 \%$ $\mathrm{HCl}$ then boiled and subsequently cooled to room temperature. $10 \mathrm{~mL}$ of $0.05 \mathrm{M}$ iodine solution was added to the mixture and shaken vigorously. The resulting solution was filtrated and titrated with 0.005 $\mathrm{M}$ sodium thiosulphate solution to calculate the iodine number $(\mathrm{mg} / \mathrm{g})$. The methylene blue number $\left(M B_{n}\right)$ was determined according to the standard method (JIS K 1470-1991). $0.05 \mathrm{~g}$ of activated carbon was mixed with methylene blue solution of concentration $25 \mathrm{mg} / \mathrm{L}$ in a conical flask and shaken for 5 hours and left for 24 hours. After equilibrium, the remaining concentration of methylene blue was determined spectrophotometrically at $\lambda_{\max }$ of $665 \mathrm{~nm}$ and calculated the methylene blue number. Further, specific surface area $\left(\mathrm{m}^{2} / \mathrm{g}\right)$ of activated carbon was determined by the methylene blue number method using multi-point adsorption isotherm based on the Langmuir model. $50 \mathrm{mg}$ of BAC was mixed with 50 $\mathrm{mL}$ methylene blue solution of concentration from 25 to $300 \mathrm{mg} / \mathrm{L}$. The solution was shaken continuously for 24 hours and left to settle down. After equilibrium, the remaining concentration of methylene blue was determined spectrophotometrically at max of $665 \mathrm{~nm}$ [25].

\section{Adsorption isotherms}

The adsorption isotherms for methylene blue and silver ions were analyzed using Langmuir and Freundlich adsorption models. The linearized Langmuir adsorption isotherm is defined as,

$$
\frac{C_{e}}{Q_{e}}=\frac{1}{Q_{\max } b}+\left(\frac{1}{Q_{\max }}\right) C_{\theta \ldots \ldots . . .(1)}
$$

Where, $\mathrm{Ce}=$ equilibrium concentration of a solution $(\mathrm{mg} / \mathrm{L})$, $\mathrm{Q}_{\mathrm{e}}=$ amount of adsorbate adsorbed by $1 \mathrm{~g}$ of adsorbent at equilibrium $(\mathrm{mg} / \mathrm{g}), \mathrm{Q}_{\max }=$ maximum amount of adsorbate adsorbed by $1 \mathrm{~g}$ of adsorbent (mg/g), b=Langmuir adsorption constant $(\mathrm{L} / \mathrm{mg})$.

The plot of $C_{e} / Q_{e}$ against $C_{e}$ gives a straight line with slope $1 / Q_{\max }$ and from intercept b can be calculated. The equilibrium parameter, $R_{L}$, was used to determine the applicability of the Langmuir isotherm which was calculated by using equation 2 .

$$
R_{L}=\frac{1}{1+b C_{o} \ldots \ldots . . . . .}
$$

Where $\mathrm{C}_{\mathrm{o}}=$ the highest concentration of adsorbate $(\mathrm{mg} / \mathrm{L})$.

The linearized Freundlich adsorption isotherm is defined as

$$
\log Q_{B}=\log K_{F}+\left(\frac{1}{n}\right) \log C_{B} \ldots \ldots \ldots .(3)
$$

Where, $\mathrm{Q}_{\mathrm{e}}=$ amount of adsorbate adsorbed by $1 \mathrm{~g}$ of adorbent at equilibrium $(\mathrm{mg} / \mathrm{g})$, and $\mathrm{K}_{\mathrm{F}}$ and $\mathrm{n}$ are Freundlich adsorption parameters, with $\mathrm{n}$ indicating adsorption 
intensity, and $\mathrm{K}_{\mathrm{F}}(\mathrm{mg} / \mathrm{g})$ the adsorption capacity of the adsorbent.

The rate and mechanism of adsorption of silver ions were analyzed by pseudo-first-order and pseudosecond-order models. The pseudo-first-order equation is given as [26].

$$
\ln \left(Q_{e}-Q_{t}\right)=\ln Q_{e}-k_{1} t
$$

Where, $Q_{e}$ and $Q_{t}$ are the amount of silver ions adsorbed $(\mathrm{mg} / \mathrm{g})$ at equilibrium and at time $t$, respectively and $k_{l}$ is the rate constant for adsorption. The values of rate constants were evaluated from the plots of $l o g$ $\left(Q_{e}-Q_{t}\right)$ versus $t$. The pseudo-second-order equation is given as [27].

$$
\frac{t}{Q_{t}}=\frac{1}{k_{2} Q_{e}^{2}}+\left(\frac{1}{Q_{t}}\right) t
$$

The plot $t / Q_{t}$ versustgives a linear curve if adsorption follows pseudo-second-order kinetics. Further, the adsorption process of activated carbon was studied by using the Intra-particle diffusion model. The linearized form of the Intra-particle diffusion model is given as [29].

$$
Q_{t}=k_{i d} t^{1 / 2}
$$

\section{Results and Discussion}

The proximate analysis of Barro seed stone suggested that it contains $2.75 \%$ ash, $2.67 \%$ moisture, 18.58 $\%$ fixed carbon, and $76 \%$ of volatile matters. The Barro seed stone, containing high volatile matter and fixed carbon but low ash and moisture, was considered as a good precursor to enhance the surface area and adsorptive capacity of the activated carbon [16]. Thermal behavior of Barro seed stone (Fig.1) shows that below $100^{\circ} \mathrm{C}$ the weight decreased slightly (about 15\%) then steeply in between 300 and $400{ }^{\circ} \mathrm{C}$ $(70 \%)$ and very slowly between 400 and $800{ }^{\circ} \mathrm{C}$. In the derivative thermogravimetric analysis (DTGA) curve, the broad peak below $100{ }^{\circ} \mathrm{C}$ indicated the evaporation of moisture and the peak between 300 and $350^{\circ} \mathrm{C}$ indicated the decomposition of hemicellulose and degradation of lignin (Fig.1). A sharp and high peak between 350 and $40^{\circ} \mathrm{C}$ revealed that the major weight loss occurred due to the degradation of cellulose at this temperature range. The lack of peak after $400^{\circ} \mathrm{C}$ attributed to that pyrolysis of Barro seed stone completed below $400^{\circ} \mathrm{C}$.

The adsorptive capacity of activated carbon depends upon the pore filling and capillary condensation mechanism $[23,30]$. The iodine and methylene blue

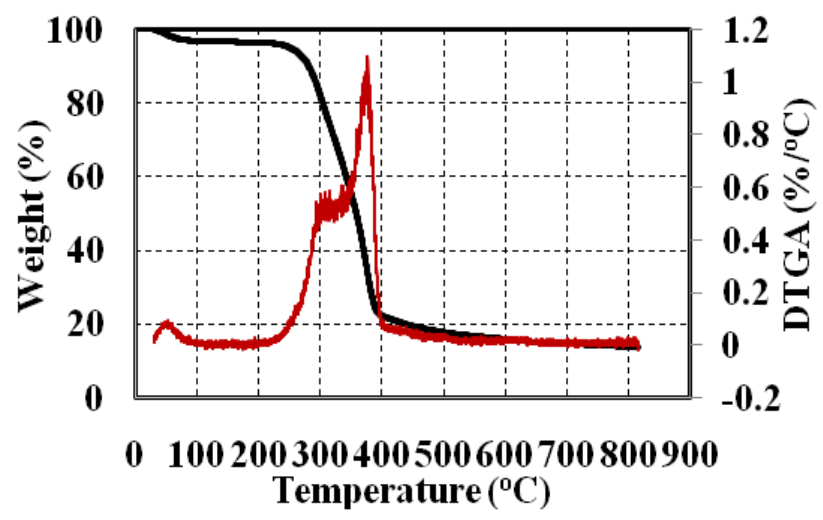

Figure 1: TG and DTG analysis of Barro seed stone

numbers represent micropores and mesopores of the activated carbon, respectively. The iodine number observed for the phosphoric acid activated carbon carbonized at 300 (BAC-300), 400 (BAC-400), and $500{ }^{\circ} \mathrm{C}$ (BAC-500) was shown in Fig.2a. The iodine number ranged from 317 to $357 \mathrm{mg} / \mathrm{g}$. It was a maximum $(357 \mathrm{mg} / \mathrm{g})$ for BAC-400. A previous study reported the iodine numbers of 367,354 , and $123 \mathrm{mg} / \mathrm{g}$ for rice husk [19], corn cob [18], and apple waste [21], respectively. Mopoung et al. [31] observed the iodine number of 150 to $300 \mathrm{mg} / \mathrm{g}$ for the activated carbon prepared from tamarind seed using a muffle furnace. As shown in Fig. 2a, methylene blue number $\left(M B_{n}\right)$ ranged from 156 to $161 \mathrm{mg} / \mathrm{g}$ for BACs and it was a maximum for the BAC-400. The iodine number and $M B_{n}$ obtained in this study were comparatively higher than those obtained for apple waste [21] and tamarind seeds [31] and comparable to those for corn cob [18] and rice husk [19] activated carbons carbonized either ina microwave or in a furnace. The specific surface area of BACs varied between 403 and $537 \mathrm{~m}^{2} / \mathrm{g}$ (Fig. 2). A maximum surface area was obtained for BAC400 similar to the iodine and methylene blue number. The effect of adsorbate dose on the adsorptive capacity of BACs was studied by varying the methylene blue concentration from 50 to $300 \mathrm{mg} / \mathrm{L}$. Fig. $2 \mathrm{~b}$ shows that the methylene blue (MB) absorption capacity of absorbent was almost $100 \%$ till the concentration of $150 \mathrm{mg} / \mathrm{L}$ and decreased slightly till $250 \mathrm{mg} / \mathrm{L}$ then decreased drastically on further increased in initial concentration. Initially, the adsorbent sites were vacant which adsorbed MB continuously, however, after covering the adsorbent sites the percentage of adsorption decreased drastically with further increase in MB concentration. These results attributed that phosphoric acid developed maximum micropores and mesopores and enhanced negatively charged surface 
area responsible for the adsorption of molecules on the surface of BAC-400 [31]. Hence, $400^{\circ} \mathrm{C}$ was considered as the best carbonization temperature for the development of pores on the surface of Barro seed stone.
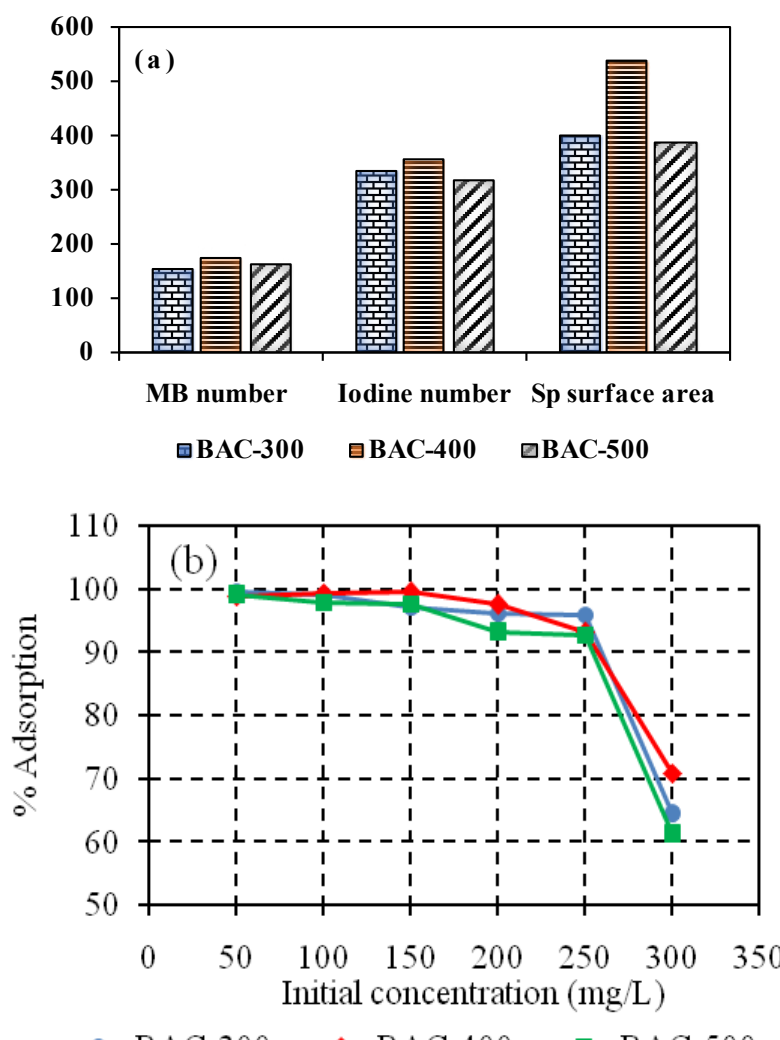

Figure 2: (a) The methylene blue number $\left(M B_{n}, m g / g\right)$, the iodine number $(\mathrm{mg} / \mathrm{g})$, and specific surface area $\left(\mathrm{m}^{2} / \mathrm{g}\right)$ of activated carbons (BACs) (b) Effect of initial concentrations on adsorption capacity of BACs

Fig.3a shows SEM images consisting of irregular sized and shaped particles. Fig. $3 \mathrm{~b}$ shows that the surface of BAC-400 was fibrous and it contains cracks and crevices and also pores of diameter less than $1 \mu \mathrm{m}$. This was the indication of the development of different sized and shaped pores on the surface of amorphous carbon which enhanced the surface area. In addition to porosity, the surface functional groups also influence the adsorption capacity of the activated carbon. The carbon atoms bonded with oxygen at the edge of carbon layers form the surface functional groups such as carboxyl, lactone, phenol, etc. [23]. These surface functional groups are responsible for the adsorption of molecules on the surface of activated carbon. The surface functional groups present on the surface of raw Barro seed stone and activated carbon were analyzed by using FTIR spectra (Fig. 4). The FTIR spectra of AC are quite similar to that of precursor although the intensity of some peaks was different. The peaks observed in the range of $3300-3800 \mathrm{~cm}^{-}$ ${ }^{1}$ can be attributed to the stretching vibrations of the $\mathrm{O}-\mathrm{H}$ group either aliphatic alcohol or phenol. The weak peaks around $1600-1800 \mathrm{~cm}^{-1}$ on the activated carbon correspond to stretching vibration $\mathrm{C}=\mathrm{O}$ in the carboxyl, ketone, aldehyde, and lactone group [32]. A broadband $1400-1600 \mathrm{~cm}^{-1}$ can be attributed to an aromatic ring or $\mathrm{C}=\mathrm{C}$ bonding. The peaks in the range of $600-800 \mathrm{~cm}^{-1}$ correspond to aromatic $\mathrm{C}-\mathrm{H}$ bending [17]. These spectra indicated that carbonyl-containing groups were developed and lignocellulosic materials were aromatized during activation.
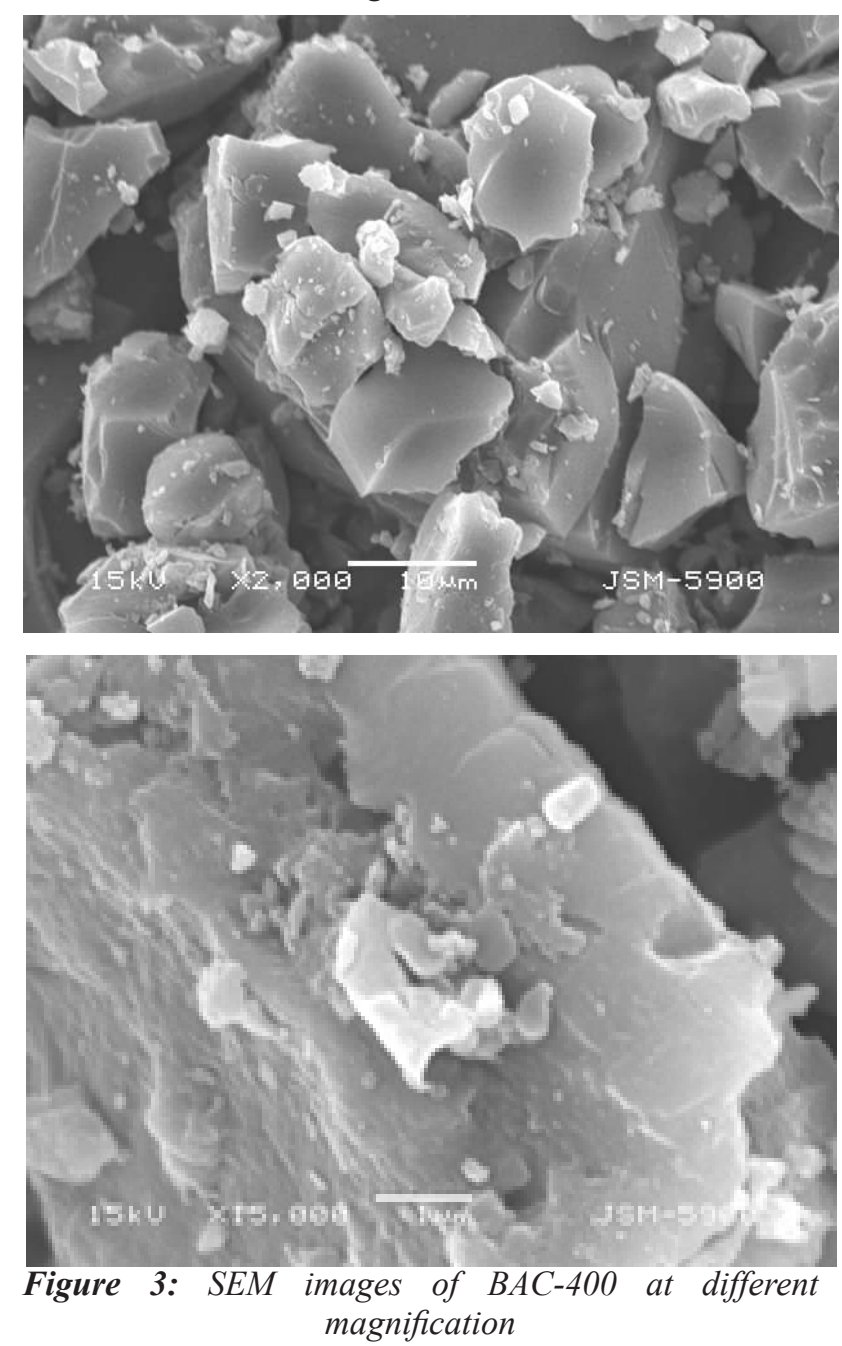

The MB adsorption was evaluated using Langmuir and Freundlich isotherms. It was found that Langmuir isotherm gives an excellent fitting to the adsorption isotherms for MB adsorption on BACs (Table 1).

The coefficient of determinant, $\mathrm{R}^{2}$, was 0.9992 , 


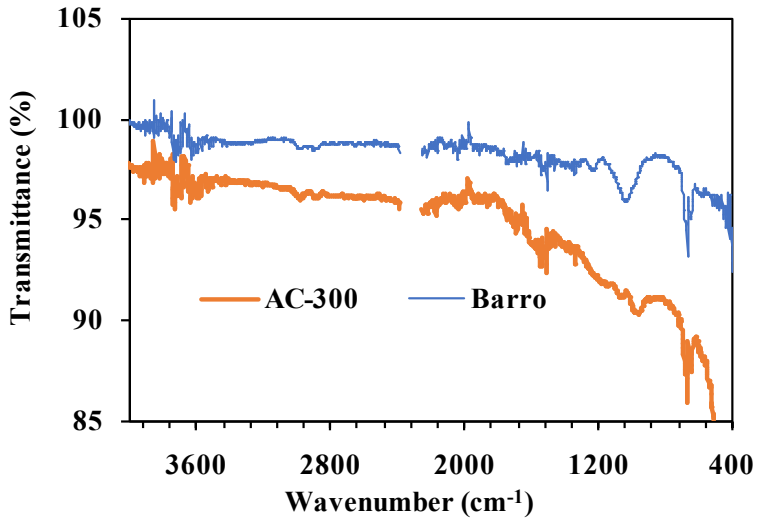

Figure 4: FTIR spectra of raw Barro seed stone and activated carbon

0.9991 and 0.9980 for BAC-300, BAC-400, and BAC-500, respectively, which suggested that chemisorption might be involved in the adsorption of MB on BACs [34].

Table 1: Langmuir and Freundlich adsorption parameters for methylene blue on activated carbons

\begin{tabular}{llll}
\hline Parameters & BAC-300 & BAC-400 & \multicolumn{1}{c}{ BAC-500 } \\
\hline$Q_{\max }(\mathrm{mg} / \mathrm{g})$ & 192.31 & 212.77 & 185.19 \\
$R_{L}(\mathrm{~L} / \mathrm{mg})$ & 0.0017 & 0.0038 & 0.0016 \\
$R^{2}$ & 0.9992 & 0.9991 & 0.9980 \\
$B$ & 4.73 & 2.14 & 4.9 \\
$K_{F}$ & 97.16 & 106.38 & 81.70 \\
$N$ & 4.31 & 4.69 & 3.95 \\
$R^{2}$ & 0.7436 & 0.5775 & 0.7141 \\
\hline
\end{tabular}

The $\mathrm{Q}_{\max }$ was highest $(212.77 \mathrm{mg} / \mathrm{g})$ for BAC400. The feasibility of the isotherm was tested by calculating the $R_{L}$ value. The $R_{L}$ value greater than zero and less than 1 indicated that Langmuir isotherm was favorable for the MB adsorption on BACs. All the observed and calculated parameters indicated that BAC-400 was the best adsorbent among the BACs, hence, it was utilized to study the removal efficiency of silver(I) ion from the aqueous solution.

\section{Silver(I) ion removal efficiency of activated carbon} (BAC)

The metal ion removal efficiency of the BAC-400 was determined by adsorbing silver $(\mathrm{Ag})$ ions from an aqueous solution. The effect of $\mathrm{pH}$ on adsorption efficiency was observed in the $\mathrm{pH}$ ranged between 2 and 8 at $1.0 \mathrm{~g} / \mathrm{L}$ of adsorbent dose and $20 \mathrm{mg} / \mathrm{L}$ of silver ion concentration (Fig 6a). Initially, the percentage adsorption of silver ion was increased with an increase in $\mathrm{pH}$ and becomes a maximum at pH 6 which was nearly $86 \%$. The adsorption was decreased drastically on further increased in $\mathrm{pH}$. The surface of activated carbon can be positively
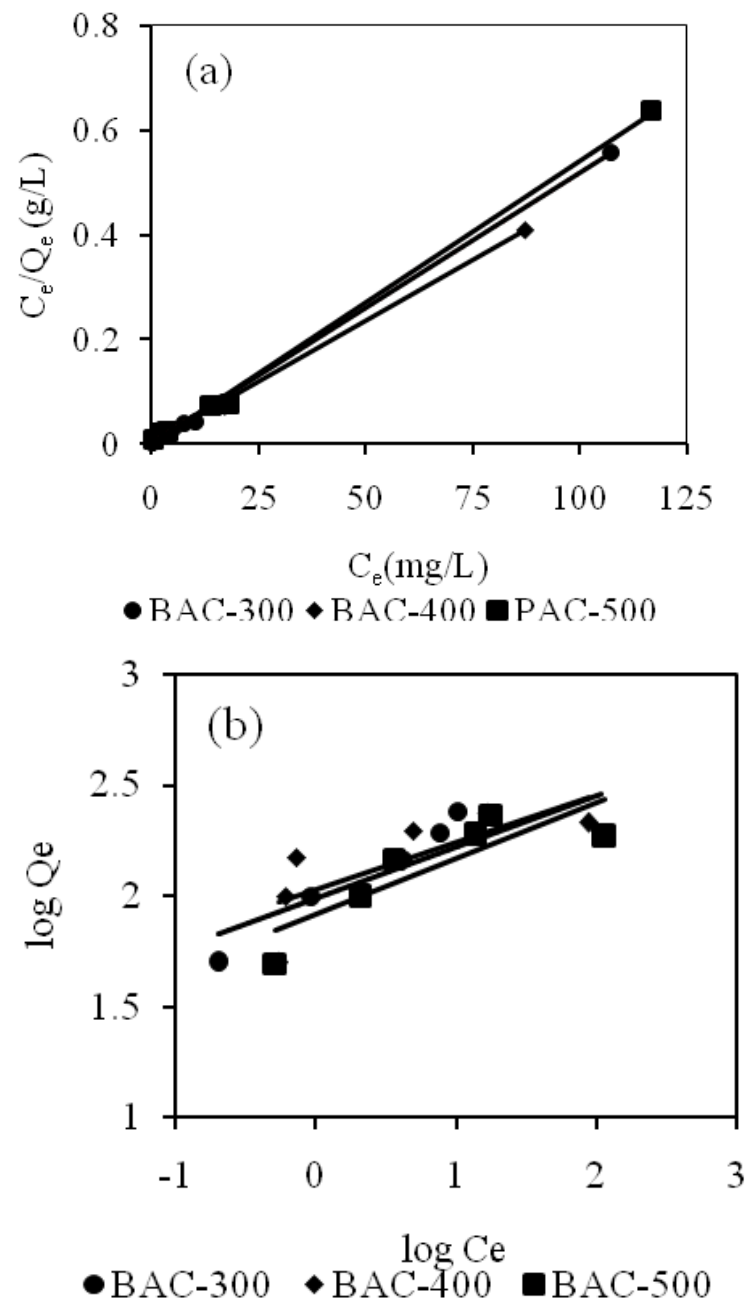

Figure 5: (a) Langmuir adsorption isotherms and (b) Freundlich adsorption isotherms of methylene blue on activated carbon

or negatively charge depending upon the $\mathrm{pH}$ of the solution [34]. At low $\mathrm{pH}$, the concentration of $\mathrm{H}^{+}$ ion in the solution is high, hence, the surface of the activated carbon becomes positively charged due to electrostatic attraction between surface-active sites of activated carbon and $\mathrm{H}^{+}$ion of the solution. This hinders the interaction between functional groups and metal ions, which significantly decreased the adsorption of a metal ion at low $\mathrm{pH}$. However, at high $\mathrm{pH}$ the concentration of $\mathrm{H}^{+}$ion in the solution is low, hence a more negatively charged surface is obtained which favors the uptake of metal ions [27]. The decreased in adsorption percentage after $\mathrm{pH} 6$ was may-be due to the masking of $\mathrm{Ag}(\mathrm{I})$ ions in the form of soluble hydroxide anion [35]. Therefore, further study of $\mathrm{Ag}(\mathrm{I})$ adsorption was conducted at $\mathrm{pH} 6$. The adsorption capacity of the adsorbent was determined by varying the amount of adsorbent dose from 0.4 to 

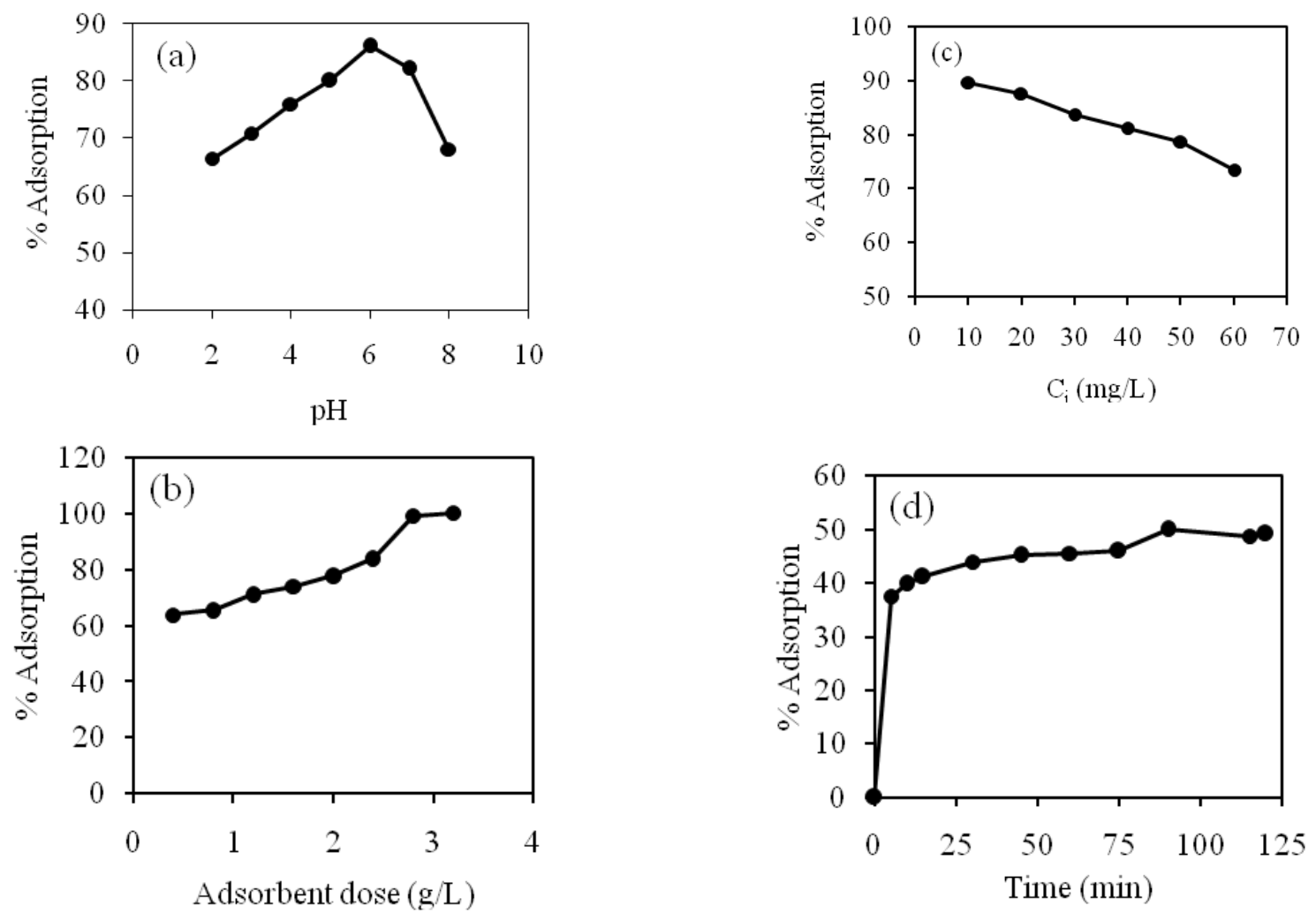

Figure 6: Effect of (a) pH, (b) adsorbent dose, (c) initial concentration, and (d) contact time on the Ag(I) ion adsorption capacity of adsorbent (BAC-400)

$3.2 \mathrm{~g} / \mathrm{L}$ (Fig 6b). The adsorption was about $64 \%$ at $0.4 \mathrm{~g} / \mathrm{L}$ and it enhanced slowly and reached $100 \%$ at $2.8 \mathrm{~g} / \mathrm{L}$ of adsorbent dose. On increasing adsorbent dose, adsorption site enhanced hence, adsorption percentage of $\operatorname{Ag}(\mathrm{I})$ ion. The percentage of adsorption at $1.0 \mathrm{~g} / \mathrm{L}$ of the adsorbent dose was about $68 \%$ and it adsorbed about $14 \mathrm{mg} / \mathrm{g}$ of silver ion. The effect of the adsorbate dose was determined by varying the initial concentration of $\mathrm{Ag}(\mathrm{I})$ ion from 10 to $60 \mathrm{mg} / \mathrm{L}$ (Fig 6c). The $\operatorname{Ag}(\mathrm{I})$ ion adsorption efficiency was about $90 \%$ at a concentration of $10 \mathrm{mg} / \mathrm{L}$ and about $87.52 \%$ at $20 \mathrm{mg} / \mathrm{L}$ and decreased continuously with an increase in dose. More than $70 \%$ was removed

Table 2: Langmuir and Freundlich adsorption parameters of $B A C-400$ for the adsorption of $\mathrm{Ag}(\mathrm{I})$ ion

\begin{tabular}{cc}
\hline Parameters & BAC-400 \\
\hline Langmuir model & \\
$Q_{\max }(\mathrm{mg} / \mathrm{g})$ & 61.72 \\
$R_{L}(\mathrm{~L} / \mathrm{mg})$ & 0.19 \\
$R^{2}$ & 0.9948 \\
$B$ & 0.1541 \\
$\Delta G(\mathrm{~kJ} /$ mole $)$ & -25.2 \\
\hline Freundlich model & 1.7 \\
$N$ & 0.9858 \\
$R^{2}$ &
\end{tabular}

even at a high concentration $(60 \mathrm{mg} / \mathrm{L})$ of $\mathrm{Ag}(\mathrm{I})$. Song et al., [13] observed $100 \%$ adsorption of $\mathrm{Ag}(\mathrm{I})$ ion at 2 ppm and 74\% adsorption at 202 ppm. Fig. 6dshows the percentage of $\mathrm{Ag}(\mathrm{I})$ ion adsorption reached $37.5 \%$ within $5 \mathrm{~min}$ then increased slowly to $50 \%$ at $90 \mathrm{~min}$. The adsorption of $\mathrm{Ag}(\mathrm{I})$ ion at equilibrium was only $68.65 \%$, it may be because of insufficient adsorption site to adsorb all $20 \mathrm{mg} / \mathrm{L}$ of $\mathrm{Ag}(\mathrm{I})$ ion i.e., low amount

Table 3: The pseudo-first and pseudo-second-order kinetics and intra-particles diffusion model parameters for the absorption of $\mathrm{Ag}(\mathrm{I})$ on $\mathrm{BAC}-400$

\begin{tabular}{cc}
\hline Parameters & PAC-400 \\
\hline Pseudo-first-order & \\
$Q_{e}(\mathrm{mg} / \mathrm{g})$ & 5.733 \\
$k_{1}\left(\mathrm{~min}^{-1}\right)$ & 0.008 \\
$R^{2}$ & 0.9029 \\
\hline Pseudo-second-order & \\
$Q_{e}(\mathrm{mg} / \mathrm{g})$ & 10.1 \\
$k_{2}(\mathrm{~g} . / \mathrm{mg} . \mathrm{min})$ & 0.0229 \\
$R^{2}$ & 0.9978 \\
\hline Intra-particle diffusion & \\
$k_{i d}\left(\mathrm{mg} / \mathrm{g} \mathrm{min}^{1 / 2}\right)$ & 0.2315 \\
$R^{2}$ & 0.9430 \\
\hline
\end{tabular}



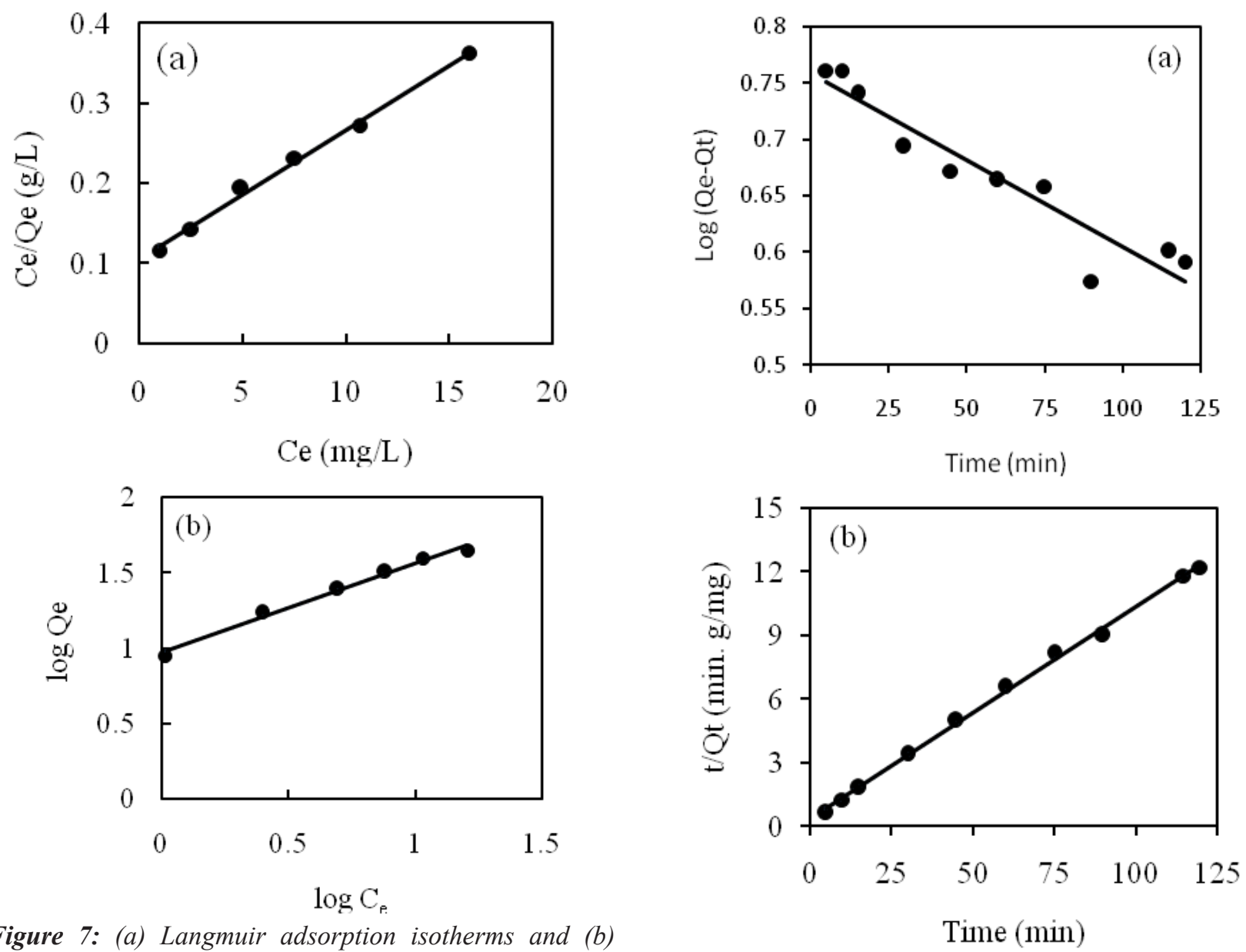

Figure 7: (a) Langmuir adsorption isotherms and (b) Freundlich adsorption isotherms for $\mathrm{Ag}(\mathrm{I})$ ion on BAC-400

of adsorbent dose (1.0 g/L) as shown in Fig 6b. Fast adsorption of $\mathrm{Ag}(\mathrm{I})$ ion attributed that a large number of adsorption sites (nanopores)were present on the surface of activated carbon [13].

The adsorption isotherm expresses the specific relation between the concentration of adsorbate and its degree of accumulation onto the adsorbent surface at a constant temperature. The silver ion removal efficiency of activated carbon was analyzed using Langmuir and Freundlich isotherm. The linearized Langmuir and Freundlich curves were shown in Fig. $7 \mathrm{a}$ and $7 \mathrm{~b}$, respectively. The corresponding Langmuir and Freundlich parameters were tabulated in Table 2. The coefficient of determinant, $\mathrm{R}^{2}$, of Langmuir and Freundlich isotherms were 0.9948 and 0.9858 , respectively. These values indicated that the adsorption of metal from aqueous solution was better fitted to Langmuir than Freundlich isotherm. The negative value of free energy $(\Delta \mathrm{G}=-25.2 \mathrm{~kJ} /$ mole) revealed the spontaneity and feasibility of the $\operatorname{Ag}(\mathrm{I})$ adsorption. The $R_{L}$ value less than 1 and greater

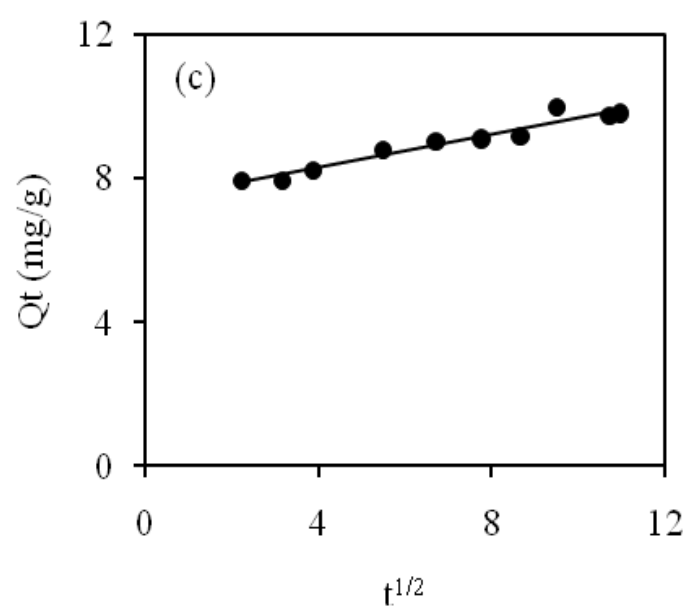

Figure 8: (a) Pseudo-first-order and (b) Pseudo-secondorder adsorption kinetics and (c) Intra-particle diffusion model plots for Ag(I) ions adsorption on BAC-400

than $40 \%$ of $\mathrm{Ag}(\mathrm{I})$ can be enhanced by increasing the adsorbent dose. The well fitted Langmuir adsorption isotherm attributed that adsorption of $\mathrm{Ag}(\mathrm{I})$ followed monolayer chemisorption. The adsorption kinetic was well fitted to the pseudo-second-order kinetics and adsorption was mainly influenced by the intra- 
than zero indicated that the Langmuir isotherm was favorable for adsorption of Ag on BAC-400 [36].

The kinetics of silver ion adsorption on BAC-400 was determined by using pseudo-first-order and pseudo-second-order adsorption models. The kinetics were studied using $\operatorname{Ag}(\mathrm{I})$ ion concentration of 20 $\mathrm{mg} / \mathrm{L}, \mathrm{pH} 6$, and an adsorbent dose of $1.0 \mathrm{~g} / \mathrm{L}$. The straight-line plot was obtained for both pseudo-first and secondary order kinetics (Fig 8). The coefficient of the determinant for pseudo-second-order kinetics (0.9978) was higher than that of pseudo-first-order kinetics (0.8717) (Table 3). The $\mathrm{Q}_{\mathrm{e}}(10.1 \mathrm{mg} / \mathrm{g})$ calculated from pseudo-second-order kinetic was higher than that from pseudo-first-order kinetic (3.22 $\mathrm{mg} / \mathrm{g}$ ) and it was nearly equal to the experimental value of $\mathrm{Q}_{\mathrm{e}}(13.11 \mathrm{mg} / \mathrm{g})$. Therefore, it was considered that the removal of $\mathrm{Ag}(\mathrm{I})$ ion from aqueous solution was limited by chemisorption promoted by nanopores developed on the surface of activated carbon. The adsorption kinetic data were further analyzed by an intra-particle diffusion model to find out the diffusion mechanism. According to this model, the $Q_{t}$ versus $\mathrm{t}^{1 / 2}$ was plotted (Fig $8 \mathrm{c}$ ). The figure shows the straightline fitting curve with a high $\mathrm{R}^{2}$ value (Table 3 ). The good linear relationship between the $Q_{t}$ and $t^{1 / 2}$ revealed that the adsorption process was controlled by intra-particle diffusion. However, the line was not passing through the origin which indicated that in addition to intra-particle diffusion other mechanisms were also involved in the $\mathrm{Ag}(\mathrm{I})$ ion adsorption [29,34].

\section{Conclusions}

Activated carbon (AC) was prepared from indigenous lignocellulosic material Barro (Terminalia-bellerica) seed stone with phosphoric acid activation. The chemically activated carbon was carbonized at three different temperatures such as 300,400 , and $500{ }^{\circ} \mathrm{C}$ for three hours in a muffle furnace. The iodine number, methylene blue number, and specific surface area of activated carbon carbonized at $400^{\circ} \mathrm{C}$ (BAC-400) were $354 \mathrm{mg} / \mathrm{g}, 173 \mathrm{mg} / \mathrm{g}$, and $537 \mathrm{~m}^{2} / \mathrm{g}$, respectively. The methylene blue adsorption on the surface of all activated carbons (BACs) followed Langmuir adsorption isotherm with maximum methylene blue adsorption capacity of $212.77 \mathrm{mg} / \mathrm{g}$ for BAC-400. Similarly, the removal efficiency of silver $(\mathrm{Ag})$ ion was more than $80 \%$ at $\mathrm{pH} 6$, and the adsorbent dosage of $3 \mathrm{~g} / \mathrm{L}$ and the $\mathrm{Ag}(\mathrm{I})$ ion concentration less than 10 $\mathrm{mg} / \mathrm{L}$. Silver ion adsorption was very fast initially, nearly $40 \%$ of silver ion was adsorbed within 5 mins at an adsorbent dosage of $1 \mathrm{~g} / \mathrm{L}$. The fast removal of more particle diffusion mechanism. The results revealed that the activated carbon prepared from Barro seed stone could be an efficient and low-cost adsorbent for the removal of methylene blue and silver ions from an aqueous solution.

\section{Acknowledgments}

The authors thank Dr. Sabita Shrestha and Dr. Khaga Raj Sharma, Central Department of Chemistry, Tribhuvan University for FTIR measurement. The authors also thank Mr. Bipin Dahal and Mr. Tanka Mukhiya, Researcher, Chonbuk National University, South Korea for recording TGA data and SEM images.

\section{References}

1. A. Garrison, The behavior of silver iodide in the photovoltaic cell. II. The Journal of Physical Chemistry, 1925, 29(1), 58-67. (DOI: 10.1021/ j150247a006)

2. J. Kottmann, U. Grob, J. M. Rey, and M.W. Sigrist, Mid-infrared fiber-coupled photoacoustic sensor for biomedical applications, Sensors, 2013, 13, 535- 549. (doi:10.3390/s130100535)

3. E. T. D. Nobrega, L.T.G. de Oliveira, A.D. Viana, H. Gasparotto Da Silva and E. P. Moraes (2019) A low-cost sensor based on silver nanoparticles for determining chemical oxygen demand in waste water via image processing analysis, Analytical Methods, 2019, 11, 5577-5583. (https://doi. org/10.1039/C9AY01755K)

4. A. Madhavan, R. Qotainy and R. Nair, Synthesis of functionalized silver nanoparticles and its application as chemical sensor, Advances in Science and Engineering Technology International Conferences (ASET), Dubai, United Arab Emirates, 2019, 1-4. (doi: 10.1109/ ICASET.2019.8714300)

5. J. Pulit-Prociak, and M. Banach, Silver nanoparticles-a material of the future?, Open Chemistry, 2016, 14(1), 76-91. (https://doi. org/10.1515/chem-2016-0005)

6. I. Sondi and B. Salopek-Sondi, Silvernanoparticles as antimicrobial agent: a case study on E. coli as a model for Gram-negative bacteria, Journal of Colloid Interface Science, 2004, 275(1), 177-182. (DOI: 10.1016/j.jcis.2004.02.012)

7. M. V. D. Z. Park, A. M. Neigh, J. P. Vermeulen, L. J. J. De la Fonteyne, H. W. Verharen, J. J. Briedé, H. V. Loveren and W. H. de Jong, The effect of particle size on the cytotoxicity, inflammation, developmental toxicity and genotoxicity of silver nanoparticles, Biomaterials, 2011, 32(36), 98109817. 
8. Z. Ferdous and A.Nemmar, (2020) Health impact of silver nanoparticles: a review of the biodistribution and toxicity following various routes of exposure, International Journal of Molecular Sciences, 2020, 21(7), 2375. (doi:10.3390/ijms21072375)

9. V. De Matteis, Exposure to inorganic nanoparticles: Routes of entry, immune response, biodistribution and in vitro/in vivo toxicity evaluation, Toxics, 2017, 5, 29. (doi: 10.3390/ toxics5040029)

10. M. J. Eckelman and T. E. Graedel, Silver emissions and their environmental impacts: a multilevel assessment, Environmental Science and Technology, 2007, 41, 6283-6289. (https:// doi.org/10.1021/es062970d)

11. S. A. Blaser, M. Scheringer, M. MacLeod, K. Hungerbuhler, Estimation of cumulative aquatic exposure and risk due to silver, contribution of nano-functionalized plastics and textiles, Science of the Total Environment, 2008, 390, 396-409. (DOI: 10.1016/j.scitotenv.2007.10.010)

12. S. Kuhr, S. Schenieder, B. Meisterjahn, K. Schlich, K. Hund-Rinke and C. Schlechtriem, (2018 Silver nanoparticles in sewage treatment plant effluents: chronic effects and accumulation of silver in the fresh water amphipod Hyalella Azteca, Environmental Sciences Europe, 2018, 30, 7. (https://doi.org/10.1186/s12302-018-0137-1)

13. X. Song, P. Gunawan, R. Jiang, K. Wang and R. $\mathrm{Xu}$, Surface activated carbon nano spheres for fast adsorption of silver ions from aqueous solutions, Journal of Hazardous Materials, 2011, 194, 162168. (DOI: 10.1016/j.jhazmat.2011.07.076)

14. S. Zafar, N. Khalid and M. L. Mirza, Potential of rice husk for the contamination of silver ions from aqueous media, Separation Science and Technology, 2012, 47, 1793-1801. (DOI: 10.1080/01496395.2012.657322)

15. A. Sari and M. Tuzen, Adsorption of silver from aqueous solution onto raw vermiculite and manganese oxide-modified vermiculite, Microporous and Mesoporous Materials, 2013, 170, 155-163. (DOI: 10.1016/j. micromeso.2012.12.004)

16. P. Ravichandran, P. Sugumaran, Ravichandran and S. Seshadri, Production and characterization of activated carbon from banana empty fruit bunch and delonixregia fruit pod, Journal of Sustainable Energy and Environment, 2012, 3, 125-132.

17. R. R. Pradhananga, L. Adhikari, R. G. Shrestha, M. P. Adhikari, R. Rajbhandari, K. Ariga and L. K. Shrestha Wool carpet dye adsorption on nanoporous carbon materials derived from agro- product, C-Journal of Carbon Research, 2017, 3, 2-12. (doi: 10.3399/c3020012)

18. M. N. Hiremath, C. B. Shivayoginath and S. N. Shivalingappa, Preparation and characterization of granular activated carbon from corn cob by $\mathrm{KOH}$ activation, International Journal of Research in Chemistry and Environment, 2012, 2, 84-87.

19. A. Cheenmatchyaa and S. Kungwankukorn, Preparation of activated carbon derived from rice husk by simple carbonization and chemical activation for using as gasoline adsorbent, International Journal of Science and Development, 2014, 5, 171-175.

20. O. Edokpayi, O. Osemwenkhae, B.V. Ayodele, J. Ossai, S. A. Fadilat, and S.E. Ogbeide, Batch adsorption study of methylene blue in aqueous solution using activated carbons from rice husk and coconut shell, Journal of Applied Sciences and Environmental Management, 2018, 22, 631635. (doi: 10.4314/jasem. v22i5.4).

21. R. H. Hesas, A.N. Arami, and J. N. Sahu, Preparation and characterization of activated carbon from apple waste by microwave assisted phosphoric acid activation, Journal of Bioresources, 2013, 8, 2950-2966.

22. R. Shrestha and S. Joshi, Isotherms and Kinetic Studies on the Adsorption of Cd(II) onto Activated Carbon Prepared from Coconut (Cocosnucifera) Shell, Journal of Nepal Chemical Society, 2019, 40, 78-83. (https://doi.org/10.3126/jncs. v40i0.27287)

23. C. Juan, M. Piraján and L. Giraldo, Activated carbon from bamboo waste modified with iron and its application in the study of the adsorption of arsenite and arsenate, Central European Journal of Chemistry, 2013, 11, 160-170. (DOI: 10.2478/ s11532-012-0138-7)

24. A. Gupta, R. Kumar, S. Kumar and K. Pandey, Pharmacological aspects of Terminalia-belerica, Molecular Biology and Pharmacognosy of Beneficial Plants, 2017, 52-64.

25. N. Samson, M. Louis and S. Sudha, (2013) Activated carbon from corn starch for treating dye waste water, International Journal of Engineering Science Invention, 2013, 2, 45-53.

26. E. L. Cochrane, S. Lu, S.W. Gibb and I. A. Villaescsa, A comparison of low-cost biosorbents and commercial sorbents for the removal of copper from aqueous media, Journal of Hazardous Materials, 2006, 137, 198-206. (DOI: 10.1016/j. jhazmat.2006.01.054)

27. F. A. Batzias and D. K. Sidiras D, Dye adsorption by pre-hydrolyzed beech saw dust in batch and 
fixed -bed systems, Bioresource Technology, 2007, 98(6), 1208-1217.

28. A. Kumar and H. Gupta, Activated carbon from sawdust for naphthalene removal from contaminated water, Environmental Technology and Innovation, 2020, 101080, 2352-1864. (DOI: https://doi.org/10.1016/j.eti.2020.101080)

29. K. M. Doke, and E. M. Khan, Equilibrium, kinetic and diffusion mechanism of $\mathrm{Cr}$ (VI) adsorption onto activated carbon derived from wood apple shell, Arabian Journal of Chemistry, 2012, 7, 31. (http://dx.doi.org/10.1016/j.arabjc)

30. S. Mahanim, I. W. Asma, J. Rafidah, E. Puad and S. Uddin (2011) Production of activated carbon from industrial bamboo wastes, Journal of Tropical Forest Science, 2011, 23, 417-424.

31. S. Mopoung, P. Moonsri, W. Palas and S. Khumpai, Characterization and properties of activated carbon prepared from Tamarind Seeds by $\mathrm{KOH}$ activation for $\mathrm{Fe}(\mathrm{III})$ adsorption from aqueous solution, The Scientific World Journal, 2015, ID 415961, 1-9. (https://doi.org/10.1155/2015/415961)

32. S. M. Anisuzzaman, C. G. Joseph, W. M. A. B. Daud, W. D. Krishnaiah and H. S. Yee, Preparation and characterization of activated carbon from Typha orientalis leaves, International Journal of Industrial Chemistry, 2015, 6, 9-21. (DOI 10.1007/s40090-014-0027-3)
33. X. P. Liao and B. Shi, Adsorption of fluoride on Zirconium (IV)- impregnated collagen fiber, Environmental Science and Technology, 2005, 39, 4628-4632. (https://doi.org/10.1021/es0479944)

34. Q. Wang, L. Liang, G. Tian, Q. Mao and X. Meng, Adsorption of azo dye malachite green onto rice wine lees: kinetic and adsorption isotherms, Nature Environment and Pollution Technology, 2020, 19(2), 563-570. (DOI: 10.46488/ NEPT.2020.v19i02.011)

35. A. Omri and M. Benzine,Adsorption characteristics of silver ions onto activated carbon prepared from almond shell, Desalination and Water Treatment, 2012, 1-10. (doi:10.1080/19443994.2012.734585)

36. H. Cai, G. Chen, C. Peng, L. Xu, X. Zhu, Z. Zhang, Y. Dong, G. Shang, F. Ke, H. Gao and $\mathrm{X}$. Wan, Enhanced removal of fluoride by tea waste supported hydrous aluminium oxide nanoparticles anionic polyacrylamide mediated aluminium assembly and adsorption mechanism, RSC Advances, 2015 5, 29266-29275. (https:// doi.org/10.1039/C5RA01560J) 